Research Article

http://dx.doi.org/10.17784/mtprehabjournal.2014.12.166

\title{
Heart rate response during a session with different active videogames.
}

Resposta da frequência cardíaca durante uma sessão com diferentes vídeo games ativos.

\author{
Jorge Luiz Brito-Gomes ${ }^{(1,2)}$, Raphael José Perrier-Melo(1,2), Fabíola Lima de Albuquerque ${ }^{(1,2)}$, Manoel da \\ Cunha Costa ${ }^{(2,3)}$. \\ University of Pernambuco (UPE), Recife (PE), Brazil.
}

\begin{abstract}
Introduction: Due to technological advancement, children and young adults pass to watching television, using the computer and playing videogames more frequently, favoring physical inactivity. However, a new form of videogames comes up as a possible tool for promoting physical activity. Objective: To examine changes in heart rate in a session with different sets of active videogames (Xbox360 with Kinect) and verified the intensities affected by the percentage of maximum heart rate. Method: 8 young adults $\left(21 \pm 1.60\right.$ years, $\left.22 \pm 1.60 \mathrm{~kg} / \mathrm{m}^{2}\right)$ with no gaming experience, performed on the Moment 1 anthropometric measurements (weight, height), hemodynamic measurements (heart rate at rest) and measurement of oxygen consumption. At Moment 2, a session with 4 different games Kinect Sports (modalities: Boxing, Table Tennis and Volleyball) and Dance Central 3. The session lasted 72 minutes (3 min each game familiarization then played for 10 minutes and then performed a passive rest 5 minutes). Throughout the session was monitored every minute heart rate. Results: There was significant increase in heart rate at different moments during the game, reaching reached $121 \mathrm{bpm} \pm 7.99,121 \pm 6.01 \mathrm{bpm}, 113 \mathrm{bpm} \pm 3.95,103 \pm 4.16 \mathrm{bpm}$ for Kinect Sports: Boxing, Dance Central 3, Kinect Sports Volleyball and Table Tennis respectively. Discussion: The games Dance Central 3 and Kinect Sports: boxing and volleyball reached moderate intensity at different times. However, the Kinect Table Tennis game showed few significant elevations. Besides presenting moments of analysis in the intensity, range considered light. Conclusion: The games analyzed caused significant increases in heart rate, reaching levels of light to moderate.
\end{abstract}

Key words: Exercise, videogames and heart rate.

\section{Resumo}

Introdução: Devido ao avanço tecnológico, crianças e adultos jovens passam a assistir televisão, usar o computador e jogar vídeo games com maior frequência, favorecendo a inatividade física. Entretanto, uma nova modalidade de vídeo games surge como uma possível ferramenta de promoção de atividade física. Objetivo: analisar alterações da frequência cardíaca em uma sessão com diferentes jogos de vídeo games ativo ( $X$ box3600 com Kinect) e verificar as intensidades atingidas por meio do percentual da frequência cardíaca máxima. Método: 8 adultos jovens ( $21 \pm 1,60$ anos; $22 \pm 1,60 \mathrm{~kg} / \mathrm{m}^{2}$ ) sem experiência com os jogos realizaram no momento 1 as medidas antropométricas (Peso, Estatura), medidas hemodinâmicas (frequência cardíaca de repouso e pressão) e medida do consumo de oxigênio. No momento 2, uma sessão com 4 diferentes jogos Kinect Sports (modalidades: Boxe, Tênis de Mesa e Vôlei) e Dance Central 3. A sessão durou 72 minutos ( 3 minutos familiarizar em cada jogo, em seguida jogavam durante 10 minutos e, posteriormente, realizavam um repouso passivo de 5 minutos). Durante toda a sessão foi monitorado a cada minuto a frequência cardíaca. Resultados: Houve elevação significativa da frequência cardíaca nos diferentes momentos no decorrer dos jogos, atingindo atingiu $121 \pm 7,99$ bpm, $121 \pm 6,01$ bpm, $113 \pm 3,95$ bpm, $103 \pm 4,16$ bpm para Kinect Sports Boxe, Dance Central 3, Kinect Sports Vôlei e Kinect Sports Tênis de Mesa respectivamente. Discussão: Os jogos Dance Central 3 e Kinect Sports: boxe e vôlei alcançaram a intensidade moderada nos diversos momentos. Entretanto, o jogo Kinect Tênis de mesa apresentou poucas elevações significativas. Além de apresentar momentos de análise na faixa de intensidade considerada leve. Conclusão: Os jogos analisados provocaram aumentos significativos da frequência cardíaca, atingindo níveis de intensidade leve à moderado.

Palavras-chave: Exercício, vídeo games e frequência cardíaca.

Received: 27 November 2013. Accepted: 13 March 2014. Published: 28 March 2014.

1. Student of the Post Graduate Program in Physical Education, University of Pernambuco (UPE), Recife (PE), Brazil.

2. Human Performance Laboratory, University of Pernambuco (UPE), Recife (PE), Brazil.

3. Professor of the Post Graduate Program in Physical Education, University of Pernambuco (UPE), Recife (PE), Brazil.

\section{Corresponding Author:}

Manoel da Cunha Costa - Address: Arnóbio de Marques Street, 310 - Bairro Santo Amaro; Recife - Pernambuco - Brazil. Zip Code: 50100-130. Phone: 3183 - 3378 - e-mail: mcosta2@gmail.com 


\section{INTRODUCTION}

Physical activity promotes the prevention and treatment of various chronic diseases, such as hypertension, obesity and diabetes, importance is already found by Caspersen, which conceptualizes physical activity as any bodily movement in energy expenditure above resting levels. ${ }^{(1,2)}$ Globalization and technological advancement the population, especially children and young adults, spent watching television, using the computer and playing video games more frequently in their daily lives. ${ }^{(3)}$ This activities discourages the practice of regular physical activity and hence favor the sedentary lifestyle that is increasingly evident in people. ${ }^{(4)}$

The traditional video games preclude the increase in body movement, as they are seated and performed with use of a joystick, so they demand less energy expenditure, with small increase in heart rate (HR) compared to active video games. ${ }^{(5)}$ According to the guidelines of the American College of Sports Medicine (ACSM) and the Center for Disease Control and Prevention $(C D C)$, it is recommended that young adult subjects perform 30-60 minutes of moderate activity (3-6 metabolic equivalents) in at least 5 days a week, with a heart rate between 50 and $69 \%$ of maximum heart rate. ${ }^{(6)}$

However, active video games (AVG's) arise as a practice that elevate levels of daily physical activity, because they mimic the experiences of real, so situations may promote health due to increased body movement, reducing hypokinesia. ${ }^{(7)}$ Miscellaneous studies found that the AVG's increase effort allowing enhanced body dynamics, raising the heart rate and thereby increasing levels of physical activity. ${ }^{(8,9,10,11)}$

In the market, you will find many AVG's, such as Xavix, Playstation Eye Toy, Nintendo Wii and Xbox 360 with Kinect, and in literature can be evidenced their comparisons. We know that the games on the Nintendo Wii may request the same metabolic equivalent when compared to Xavix and other AVG's. ${ }^{(7)}$

Games Xbox360 0 with Kinect may require greater metabolic equivalent and oxygen consumption when compared to the games of the Nintendo $\mathrm{Wii}^{(11)}$, as well as greater energy expenditure, oxygen consumption, metabolic equivalents $^{(12)}$ and heart rate. ${ }^{(13)}$ Thus, the general objective of the study was to analyze the response of heart rate in a session with different sets of active video games (Xbox360 0 with Kinect) and check the intensities attained by each game, as the percentage of maximum heart rate (according to ACSM ) that different games held during a session.

\section{METHODS}

Pre-experimental study in which the sample was composed of eight students, aged between 18 and 25 apparently healthy (PARQ), eutrophic, male, not physically active, unrestricted osteo-articular muscle that prevent the achievement of physical activity, no ex- perience on active video game (AVG) and assets that proposed to participate voluntarily by signing the consent form and presented PAR-Q questionnaire negative video. Were excluded those who missed the session or failed to perform the complete session.

The present study has a positive appreciation of the University of Pernambuco (UPE) Research Ethics Committee on the number of opinion 205 415. The subjects received prior instruction about the objectives, procedures and risks besides the confidentiality of the information to be acquired, and agreeing to participate voluntarily signed an informed consent form.

Individuals were followed in two stages: at first underwent anamnesis (PAR-Q was used to identify the health status of the individual) and signed an informed consent form. After positive procedures performance on subject, were performed anthropometric measurements (weight and height), hemodynamic measurement (resting heart rate) and measured oxygen consumption.

Body weight in kilograms was measured using a mechanical scale (Filizola, Brazil), with accuracy of 0.1 $\mathrm{kg}$. Stature was measured in centimeters using a wooden stadiometer fitted with a scale in millimeters. Anthropometric measurements were performed by trained professionals and obeyed by ISAK standardized international techniques. ${ }^{(14)}$ To the extent the HR, heart rate monitor (Polar FT1) was used. Oxygen consumption was obtained using a submaximal test performed on a cycle ergometer (Cateye EC-1600 Ergociser) following the protocol of Astrand-Ryhming (1954). ${ }^{(15)}$

For the tests, the volunteers were instructed to use the minimum of clothing, not perform moderate or vigorous exercise in the last 24 hours prior to data collection, feed at least three hours before the measurements and refrain from alcohol and smoke the day before.

On the second moment, the session was held 4 different games on an active games video device. The console used was Kinect Xbox $360^{\circ}$. The projected image was transmitted through a multimedia projector power lite $\mathrm{S} 10+($ EPSON) attached to the ceiling of the room and connected to the console projecting an image of approximately 1.3 meters high by 1.6 meters wide (82 inches). The video system used was one amplified speaker multipurpose COM 126 Professional (ONEAL, Brazil) connected to the console. All stages of the study were performed in the Laboratory Evaluation in Human Performance CENESP-PE/ESEF/UPE, at $24 \pm 2$ - $C$ temperature, 40-60\% relative humidity and atmospheric pressure of approximately $760 \mathrm{mmHg}$.

The experimental session consisted of sequentially playing different games, in which the intensity was uniform at the beginner level for all subjects and games, because of lack of experience with active video games. Four games were used, three from Kinect Sports in the modalities: Boxing, Table tennis and Volleyball, and one 


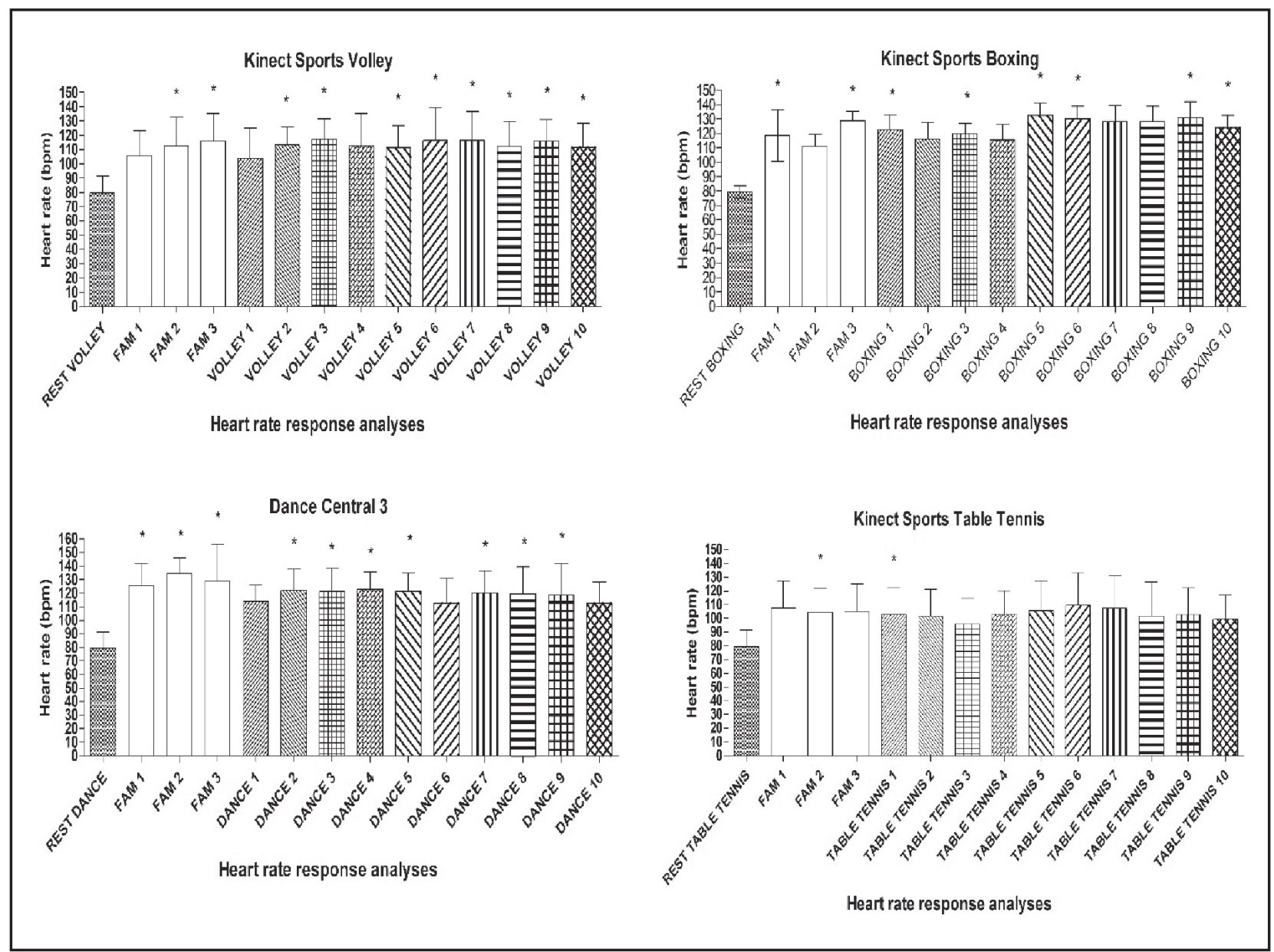

Figure 1. Heart rate response during games. REST = Rest in sitting position;

FAM $=$ Familiarization in the game.

of dance: Dance Central 3. The following games were randomized into four series: A) Boxing / Volleyball / Dance / Table Tennis, B) Volleyball / Dance / Tennis / Boxing, C) Dance / Tennis / Boxing / Volleyball and D) Tennis table / Boxing / Volleyball / Dance.

Table 1. Sample characterization recruited for the study $(n=8)$.

\begin{tabular}{lc}
\hline Variable & $\begin{array}{c}\text { Mean } \pm \text { standard } \\
\text { deviation }\end{array}$ \\
\hline Age (years) & $21 \pm 1.60$ \\
Weight (kg) & $71.0 \pm 4.2$ \\
Stature (cm) & $177 \pm 4$ \\
BMI (kg/m²) & $22 \pm 1.60$ \\
Aerobic capacity (ml/kg/min $\left.{ }^{-1}\right)$ & $39 \pm 9.0$ \\
Heart Rate (bpm) & $80 \pm 12.6$ \\
Resting Heart Rate (bpm) & $121 \pm 7.99$ \\
HR Kinect Sports Boxing (bpm) & $121 \pm 6.01$ \\
HR Dance Central 3 (bpm) & $113 \pm 3.95$ \\
HR Kinect Sports Volleyball (bpm) & $103 \pm 4.16$ \\
\hline HR Kinect Sports Table tennis (bpm) &
\end{tabular}

BMI - Body Mass In dex; BPM - Beats per minute; HR - Average heart rate referring to 13 minutes per game.
The date on which the subject was referred to the completion of the session, the draw of the experimental session was conducted series (all subjects were equally likely to withdraw any lot, however, each series was performed twice due to sample size). This procedure was performed in order to avoid the accumulation of workload performed between games.

The experimental session lasted a total of 72 minutes, divided as follows: the subjects started with three minutes to familiarization, then played for 10 minutes and then performed a passive sitting position at rest for a period of 5 minutes. Throughout the session was to measure heart rate, which was recorded every minute.

Data were tabulated in Excel (2013) and transported into SPSS (20.0) program. A priori, it was performed an exploratory analysis of data, normality test (Shapiro-Wilk) and (mean, standard deviation and relative frequency) descriptive measures. One Way ANOVA with post hoc Bonferroni test was performed to analyze the difference between rest and moments of measures. We used a significance level of $5 \%(p<0.95)$ for all analyzes. 


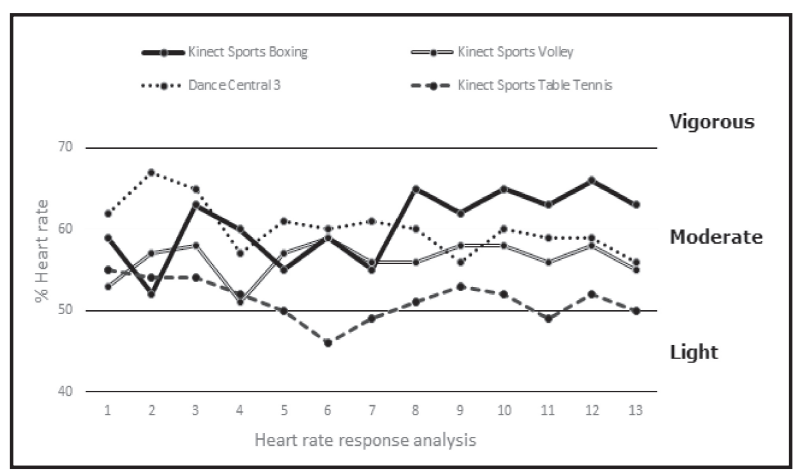

Figure 2. Percentual analysis of heart rate in times of measurement ranges and intensity according to the ACSM guidelines.

\section{RESULTS}

The sample was homogenized as the average oxygen consumption, subjects classified as regular as the ACSM and the American Heart Association. ${ }^{(6)}$ Are presented in Table 1, data from sample characterization and hemodynamic variable during each game session analyzed (time 2).

By observing the thirteen moments in each of the different sets of AVG's, we note that Dance Central and Kinect Sports games: volleyball and boxing show significant increases in heart rate variable largely practice compared to the rest, however only the game Kinect Sports: table tennis, not presented on more than two occasions, significant increases compared to rest as can be seen below in Figure 1.

According to the recommendations of the American College of Sports Medicine ${ }^{(16)}$, it can be stated that during the intervention with various games, a level of mild to moderate intensity as shown in Figure 2 has been reached.

\section{DISCUSSION}

The present study aimed to analyze the response in heart rate during a session with different sets of active video games and check the strength attained by the percentage of maximum heart rate. By analyzing the heart rate, a significant increase compared to rest in all games was observed. It was expected, as found in this study, elevated heart rate, regarding rest, once during the execution of any physical exertion, increased blood supply to the heart muscle, and muscle activity. ${ }^{(17)}$

Thus, when analyzing the changes in heart rate during the intervention with different games Xbox Kinect, it is observed that the Dance Central 3 and Kinect Sports games: boxing and volleyball, showed significant increases in chronotropic various times during the session compared at rest, as shown in Figure 1.

However, boxing match, showed higher values, similar to the result obtained in Smallwood, Morris, Fallows, \& Buckley study, in which the Kinect boxing game had greater increases in heart rate compared to Dance
Central.(11) Corroborating with the results found in the study by Kafri, Myslinski, Gade, \& Deutsch, the game Kinect Sports Boxing achieved a moderate level of intensity. ${ }^{(18)}$

The games increased the resting heart rate (average $80 \mathrm{bpm}$ ) to $103 \pm 4.16 \mathrm{bpm}$ (Kinect Table Tennis), $113 \pm 3.95 \mathrm{bpm}$ (Kinect Volleyball), $121 \pm 6.01$ bpm (Dance Central) and $121 \pm 7.99$ bpm (Kinect Boxing) between games as shown in Table 1. Results found in the similarly study of Graves et al, in which it was found that the Wii boxing game had higher elevations on comparisons to other games studied (Wii Tennis and Wii Bowling), reaching an average of 136 bmp, considered moderate. ${ }^{(8)}$

In the present study we found that the participants during different times of the games have reached a general level of intensity considered moderate. However, analyzing the percentage of intensity reached, the game Kinect Sports Table Tennis, was the one who showed moments at low intensity, getting only two significant increases as shown in Figure 2. In contrast, in the study by Taylor et al, the game Kinect Table Tennis, was considered overall a mild activity, according to their metabolic equivalents. ${ }^{(12)}$

However, when analyzing the average percentage of heart rate, the games had an average of: $62.81 \%$ boxing, 59.79\% dancing, 56.78\% volleyball and $51.75 \%$ table tennis, in which, according to ACSM activities are considered with a level of moderate intensity (50-69\%). (6) These amounts are not considered severe, possibly because it was used in all games at the beginner level. These conditions do not have enough game to produce changes demands a vigorous-intensity physical activity. ${ }^{(19)}$

Similar to the study by Smallwood, Morris, Fallows, \& Buckley, in this study there was no accumulation of activity, which can be shown by the values of heart rate, since there was a passive rest lasting 5 minutes. ${ }^{(11)}$ For example, boxing gave peak heart rate on familiarization in 3 minutes, as well as the three-minute familiarization dancing with abrupt elevation, with the highest peaks of HR this game. Can be given to the fact that this new activity not performed before, cause sufficient to alter various physiological systems changes. ${ }^{(20)}$ Moreover, the practice with active games can cause cardiovascular changes by the great body movement during your practice, requiring recruit a greater number of muscle mass involved during the activity, ${ }^{(21)}$ such as the dance game, which has membership of jumps during its execution.

\section{CONCLUSION}

The results show that active video games significantly increased heart rate during the matches, however, the table tennis game got few significant elevations compared to rest. Through the percentage of maximum 
heart rate, the game Kinect table tennis had moments considered mild, but being conceptualized as moderate overall. The Kinect boxing, Kinect volleyball and dance
(Dance Central 3) offered at all times of analysis moderate-intensity according to the guidelines of the American College of Sports Medicine.

\section{REFERENCES}

1. Caspersen CJ, Powell KE, Cristensen GM. Physical activity, exercise, and physical fitness: definitions and distinctions for health-related research. Public Health Reports. 1985;100(2):172-179.

2. Nahas, MV. Atividade física, saúde e qualidade de vida: conceitos e sugestões para um estilo de vida ativo. 4. ed. Londrina: Midiograf, 2006

3. Christie B, Trout J. Rather than contribute to a sedentary lifestyle, these games demand activity from the players. Interac Vid Game Phys Educat. 2007;78(5).

4. Graves LE, Ridgers ND, Williams K, Stratton G, Atkinson G, Cable NT. The physiological cost and enjoyment of Wii Fit in adolescents, young adults, and older adults. J Phys Act Health. 2010;3:393-401.

5. Lanningham-Foster L, Foster RC, McCrady SK, Jensen TB, Mitre N, Levine JA. Activity-promoting video games and increased energy expenditure. J. Pediatr. 2009;154(6):819-23.

6. Haskell WL, Lee IM, Pate RR, Powell KE, Blair SN, Franklin BA, et al. Physical activity and public health: updated recommendation for adults from the American College of Sports Medicine and the American Heart Association. Med Sci Sports Exerc. 2007;39(8):1423-34.

7. Bailey BW, McInnis K. Energy cost of exergaming: a comparison of the energy cost of 6 forms of exergaming. Arch Pediatri Adolesc Med. 2011;165(7):597-602.

8. Graves LE, Ridgers ND, Stratton G. The contribution of upper limb and total body movement to adolescents' energy expenditure whilst playing Nintendo Wii. Eur J Appl Physiol. 2008;104(4):617-623.

9. Douris PC, McDonald B, Vespi F, Kelley NC, Herman L. Comparison between nitendo wii fit aerobics and tradicional aerobic exercise in sedentary young adults. J Strength Cond Res. 2012 Apr;26(4):1052-7.

10. Roemmich JN, Lambiase Ms MJ, McCarthy TF, Feda DM, Kozlowski KF. Autonomy supportive environments and mastery as basic factors to motivate physical activity in children: a controlled laboratory study. International J Behav Nutr Phys Act. 2012;21:9-16. doi:10.1186/1479-5868-9-16

11. Smallwood SR, Morris MM, Fallows SJ, Buckley JP. Physiologic responses and energy expenditure of kinect active video game play in school children. Arch Pediatr Adolesc Med. 2012;166(11):1005-9. doi:10.1001/archpediatrics.2012.1271.

12. Taylor LM, Maddison R, Pfaeffli LA, Rawstorn JC, Gant N, Kerse NM. Activity and energy expenditure in older people playing active video games. Arch Phys Med Rehabil. 2012;93(12):2281-6. doi:10.1016/j.apmr.2012.03.034

13. O'Donovan C, Hirsch E, Holohan E, McBride I, McManus R, Hussey J. Energy expended playing Xbox Kinect ${ }^{T M}$ and Wii ${ }^{\mathrm{TM}}$ games: a preliminary study comparing single and multiplayer modes. J Physioth. 2012;98(3):224-9.

14. ISAK - International Society for the Advancement of Kinantropometry, I. Inter Standards Anthro Assess. Australia 2011.

15. Heyward VH. Avaliação e prescrição de exercício: técnicas avançadas/ Vivian H. Heyward; trad. Márcia Dorneles - 40.ed. p.69 - Porto Alegre, 2004.

16. Garber CE, Blissmer B, Deschenes MR, Franklin BA, Lamonte MJ, Lee IM, et al. American College of Sports Medicine position stand. Quantity and quality of exercise for developing and maintaining cardiorespiratory, musculoskeletal, and neuromotor fitness in apparently healthy adults: guidance for prescribing exercise. Med Sci Sports Exerc. $2011 ; 43(7): 1334-59$.

17. McArdle WD, Katch FI, Katch VL. Fisiologia do exercício: nutrição, energia e desempenho humano. 7. ed. Rio de Janeiro: Guanabara 2011.

18. Kafri M, Myslinski MJ, Gade VK, Deutsch JE. Energy expenditure and exercise intensity of interactive video gaming in individuals poststroke. Neurorehabil Neural Repair. 2013;28(1):56-65. doi:10.1177/1545968313497100

19. O'donavan $\mathrm{C}$, Roche EF, Hussey J. The energy cost of playing active video games in children with obesity and children of a healthy weight. J Pediatr Obesity. 2013 Apr 29. doi: 10.1111/j.2047-6310.2013.00172.x. [Epub ahead of print].

20. Pellegrini AM. A Aprendizagem De Habilidades Motoras I: O Que Muda Com A Prática? Rev. paul. Educ. Fís. 2000;Supl.3:29-34, 2000.

21. Souza RA. Cruz LG, Carvalho PS, Silva FF, Carvalho WRG. Respostas cardiovasculares agudas em ambiente virtualmente simulado pelo Nintendo Wii. Rev. Bras. Cineantrope Desempenho Hum. 2013;15(1):60-70. 